\title{
Passive Seismic Experiment "13 BB Star" in the Margin of the East European Craton, Northern Poland
}

\author{
Marek GRAD ${ }^{1}$, Marcin POLKOWSKI ${ }^{1}$, Monika WILDE-PIÓRKO ${ }^{1}$, \\ Jerzy SUCHCICKI ${ }^{2}$, and Tadeusz ARANT ${ }^{2}$ \\ ${ }^{1}$ Institute of Geophysics, Faculty of Physics, University of Warsaw, Warsaw, Poland \\ e-mail: mgrad@mimuw.edu.pl (corresponding author) \\ ${ }^{2}$ Institute of Geophysics, Polish Academy of Sciences, Warsaw, Poland
}

\begin{abstract}
The lithosphere-asthenosphere boundary (LAB) is investigated recently very effectively, mostly using seismic methods because of their deep penetration and relatively good resolution. The nature of LAB is still debated, particularly under "cold" Precambrian shields and platforms. Passive experiment " 13 BB star" is dedicated to study deep structure of the Earth's interior in the marginal zone of the East European craton in northern Poland. The seismic network consists of 13 broadband stations on the area of $c a .120 \mathrm{~km}$ in diameter. The network is located in the area of well-known sedimentary cover and crustal structure. Good records obtained till now, and expected during next 1-year long recording campaign, should yield images of detailed structure of the LAB, „410”, "?520”, and „660" km discontinuities, as well as mantle-core boundary and inner core.
\end{abstract}

Key words: East European craton, lithosphere, asthenosphere, seismic passive experiment, broadband seismology.

Ownership: Institute of Geophysics, Polish Academy of Sciences;

(C) $2015 \mathrm{Grad}$ et al. This is an open access article distributed under the Creative Commons Attribution-NonCommercial-NoDerivs license,

http://creativecommons.org/licenses/by-nc-nd/3.0/. 


\section{INTRODUCTION}

The nature of a transition from a rigid plate - the lithosphere, to a weaker layer below, the asthenosphere, is still debated. Till now our understanding of the lithosphere-asthenosphere boundary (LAB) is limited in comparison to other interfaces in the Earth, e.g., Moho, " $410 \mathrm{~km}$ ", " $670 \mathrm{~km}$ ", and mantlecore boundary. The thickest lithosphere, in excess of $200 \mathrm{~km}$, is observed under "cold" Precambrian shields and platforms, while the thinnest lithosphere, of 50-100 km, was found under "hot" oceans and oceanic and continental rifts. The depth of oceanic LAB is widely accepted, why continental LAB is very often difficult to detect. For example, lithospheric thickness of the Baltic Shield has estimates varying between 160 and $350 \mathrm{~km}$. Another controversy relates to nature of LAB. Recent estimates and modellings suggest $\mathrm{LAB}$ to be a first-order structural discontinuity that accommodates differential motion between tectonic plates and the underlying mantle (e.g., Eaton et al. 2009). According to other opinions, LAB is not a sharp discontinuity, but rather gradual and wide transition zone (see, e.g., Meissner 1986, Bartzsch et al. 2011).

The lithosphere-asthenosphere boundary (LAB) is investigated recently very effectively, mostly using seismic methods because of their deep penetration and relatively good resolution. Comparison of $S$-wave velocity changes with depth in the upper mantle obtained from global tomographic models shows that velocities under cratons are greater than under oceans (Fig. 1a). This figure shows also that LAB is rather gradual and wide transition zone, and velocity-depth curve illustrates the difficulty in identifying a signature of the lithosphere-asthenosphere boundary (Romanowicz 2009). In general, velocities under cratons are greater than under oceans down to $200 \mathrm{~km}$ depth, and velocity decreases with depth, with a minimum centred at 100 to $150 \mathrm{~km}$ under the oceans and 200 to $250 \mathrm{~km}$ in the cratons. Regional 1D $S$-wave velocity models obtained for the central part of Baltic Shield from SVEKALAPKO array shows that velocities beneath the craton are significantly higher (about $4 \%$ down to a depth of $250 \mathrm{~km}$ ) compared to standard model iasp91 (Bruneton et al. 2004). On the other hand, lowering of the velocity with depth is not visible (Fig. 1b; Sandoval et al. 2004, Kozlovskaya et al. 2008). This fact could be interpreted as a lack of asthenosphere, or that LAB in this area occurs deeper. Shear wave velocity in southern Tibet shows clearly lowering velocity in the depth range of $120-300 \mathrm{~km}$, which could be interpreted as the asthenosphere (Fig. 1c; Jiang et al. 2011).

Passive seismic experiment " 13 BB star" is dedicated to study LAB and deep structure of the Earth's interior in the marginal zone of the East European craton in northern Poland. The Precambrian East European craton (EEC) is the coherent part of Europe that occupies the north-eastern half of 

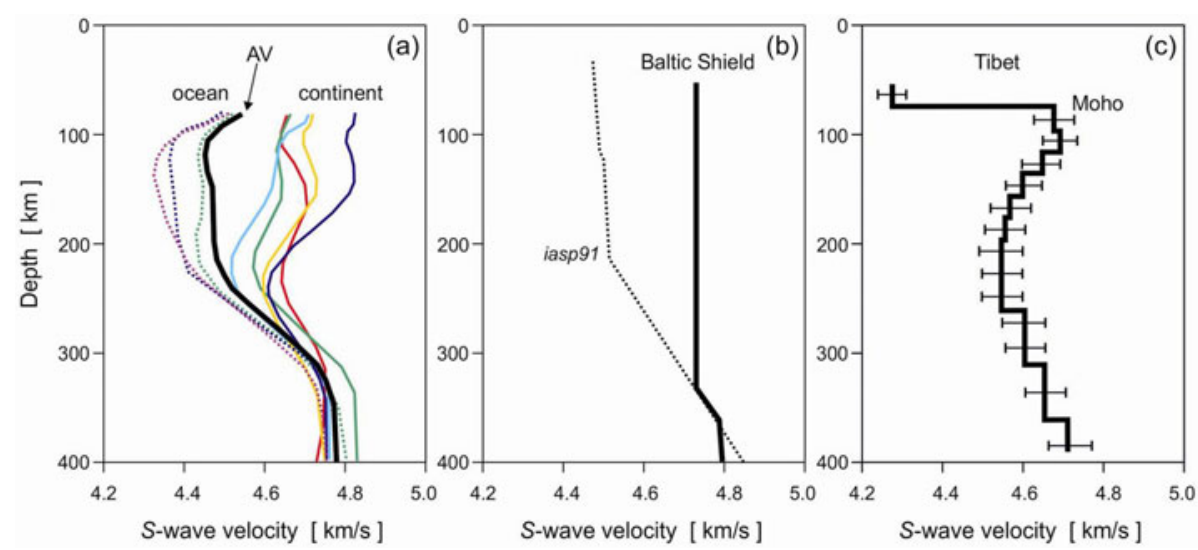

Fig. 1. Comparison of shear-wave slowdown for different regions of the Earth: (a) Shear-wave velocity changes with depth in the upper mantle from global tomographic model. Dashed lines are for oceanic mantle (pink for Pacific, blue for midAtlantic ridge, and green for Indian Ocean, south of Madagascar) and solid lines are for continental mantle under cratons (light blue for northern area of South America, green for NW part of Africa, red for Western Siberia, orange for Central Australia, and deep blue for NE part of North America). Thick black line (AV) is global average. Velocities under cratons are greater than under oceans down to $200 \mathrm{~km}$ depth, and velocity decreases with depth, with a minimum centred at 100 to $150 \mathrm{~km}$ under the oceans and 200 to $250 \mathrm{~km}$ in the cratons; (b) $1 \mathrm{D} S$-wave velocity model obtained for the central part of Baltic Shield at the station FJ01 from SVEKALAPKO array (solid line) compared to standard model iasp91 (thin dashed line; Kennett and Engdahl 1991); (c) 1D average shear wave velocity in southern Tibet (solid line with error bars). Compilation from Romanowicz (2009), Jiang et al. (2011), and Kozlovskaya et al. (2008).

the continent. In the south and west of EEC, the Trans-European suture zone (TESZ) separates the Precambrian terranes of the craton from the younger Phanerozoic terranes of middle to late Palaeozoic accretion and deformation (Fig. 2; Znosko 1975, 1979, Pożaryski et al. 1982, Ziegler 1990, Pharaoh et al. 1997, Berthelsen 1998, Grad et al. 2002, Bogdanova et al. 2006). The TESZ correlates with a gravity minimum (e.g., Królikowski and Petecki 1997, Krysiński et al. 2000, Grabowska et al. 2011), high heat flow values (e.g., Majorowicz et al. 2003), and electromagnetic properties of the lithosphere (e.g., Jóźwiak 2013).

\section{2. "13 BB STAR" EXPERIMENT}

To study the deep structure of the Earth's interior, location of "13 BB star" network was chosen in northern Poland, in the marginal zone of EEC (Figs. 2 and 3). This area is well recognised in terms of both the velocities of 


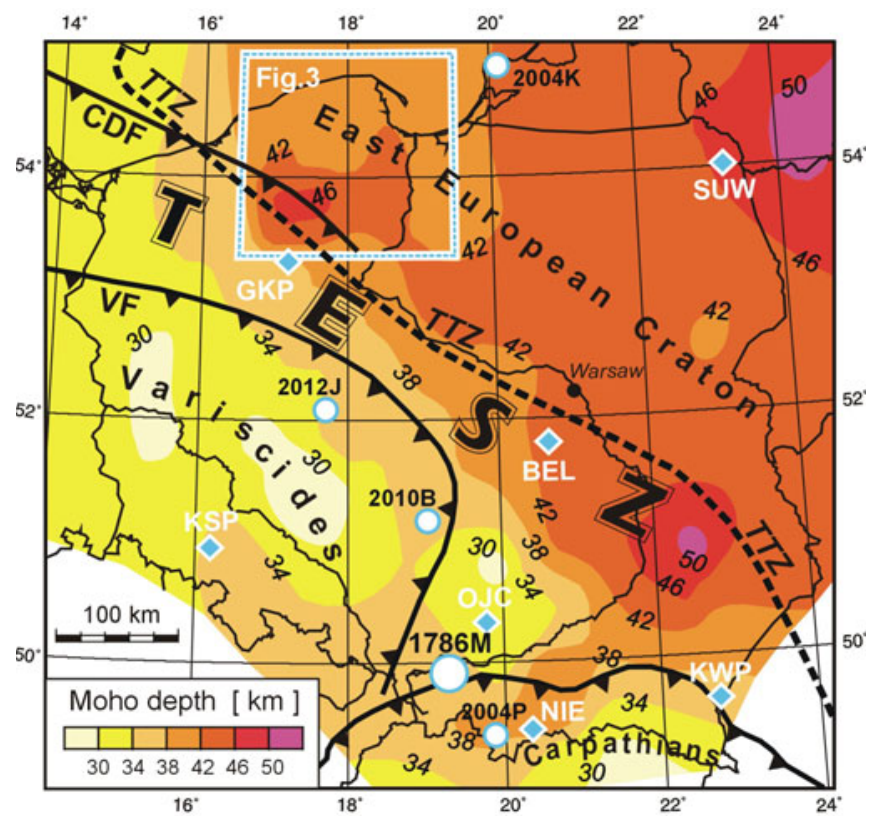

Fig. 2. Location of seismic stations in Poland on the background of the Moho depth map (Guterch and Grad 2006) with main tectonic elements of the area: CDF - Caledonian Deformation Front, TESZ - Trans-European Suture Zone, TTZ - TeisseyreTornquist Zone, VF - Variscan Front. Seven permanent broadband seismic stations are marked by blue diamonds (SUW, GKP, BEL, KSP, OJC, NIE, KWP). White dots show location of five strongest seismic events which occurred during the past decade in the study area: 2004K (two events near Kaliningrad, 21 September 2004, $M_{W}=5.1$ and 5.2; Domański 2007), 2012J (Jarocin, 6 January 2012, $M_{L}=3.8$; Lizurek et al. 2013); 2010B (Bełchatów, 22 January 2010, $M w=4.3$; Wiejacz and Rudziński 2010), 2004P (Podhale, 30 November 2004, $M_{b}=4.7$; Wiejacz and Dębski 2009). Big dot shows location of largest earthquake known to have ever taken place in Poland 1786M (Myślenice, 3 December 1786, $M=5.6$; Pagaczewski 1972). White-blue rectangular shows location of "13 BB star" passive experiment in northern Poland, in the edge of the East European craton (for details see Fig. 3).

sedimentary layer and the crustal structure (Skorupa 1974, Grad et al. 2003, Grad and Polkowski 2012). Precise knowledge of velocities and thickness of sediments is based on borehole data (VSP - vertical seismic profiling). The mean velocity of the sedimentary cover increases with thickness and varies from $2.5 \mathrm{~km} / \mathrm{s}$ where these strata are $1 \mathrm{~km}$ thick to about $4.3 \mathrm{~km} / \mathrm{s}$ where they are $8 \mathrm{~km}$ thick (Grad 1986). In northern Poland, the depth of the crystalline basement is $1-2 \mathrm{~km}$ and increases toward the south-west to $7-8 \mathrm{~km}$ in the margin of the EEC, which is known both from borehole data and seismic re- 


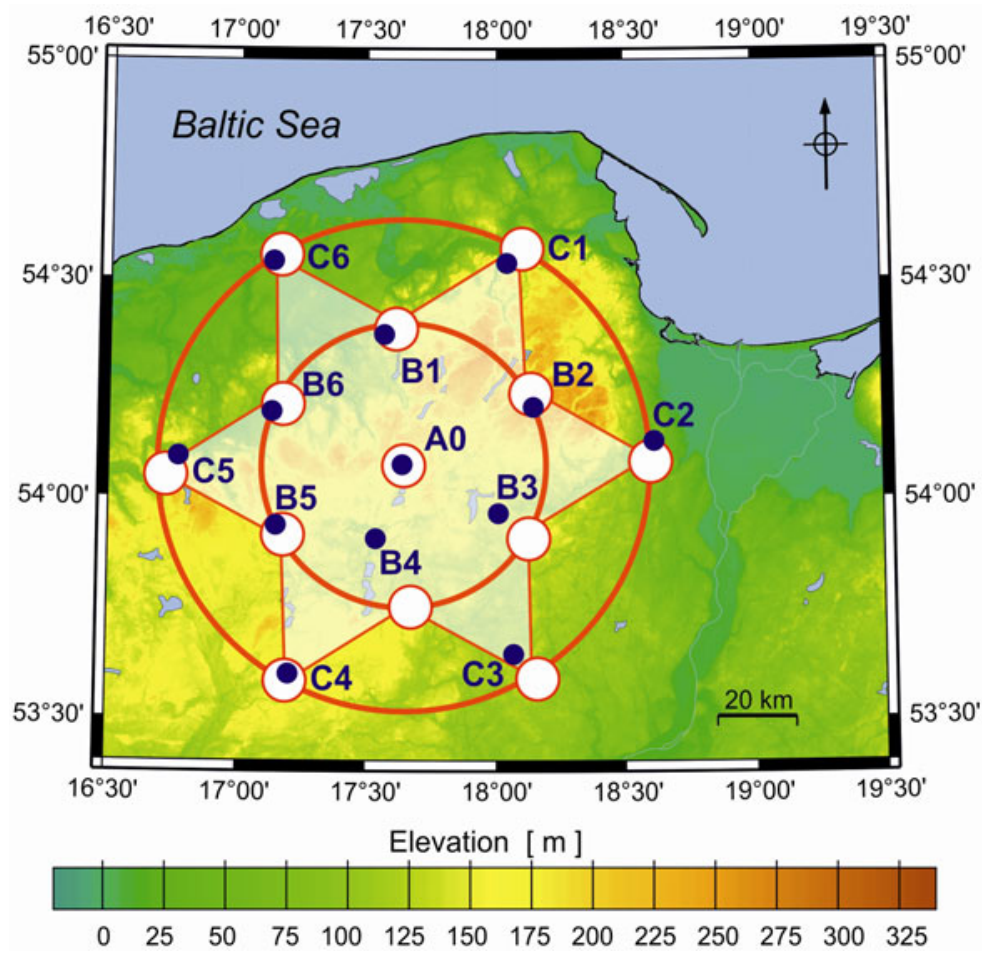

Fig. 3. Location map of " 13 BB star" network in northern Poland on the background of the topography map. Red dots and circles show the planed regular geometry of the network where broadband seismometers are placed in basic equilateral triangles with side lengths of $35 \mathrm{~km}$. The navy-blue dots are final locations of the stations (A0, B1-B6, C1-C6).

fraction (Skorupa 1974, Młynarski 1984). In the area of "13 BB star" network the Proterozoic basement has an age of 1.85-1.80 Ga (Bogdanova et al. 2006). The crystalline crust has a three-layer structure that is typical for EEC, with $P$-wave velocities of 6.1-6.4, 6.5-6.8, and $6.9-7.2 \mathrm{~km} / \mathrm{s}$ in the upper, middle, and lower parts, respectively. Surrounding Moho depth is also well known there (see Fig. 2; Guterch and Grad 2006, Grad et al. 2009, Majdański 2012, Malinowski 2013). The Moho topography is relatively flat (about $40-45 \mathrm{~km}$ beneath stations), which also is favourable from the point of view of deep structure studies. The assumed shape of network is shown in Fig. 3. Red circles and red/white dots show the assumed regular geometry of the network where seismometers are placed in basic equilateral triangles with side lengths of $35 \mathrm{~km}$. All places for stations were found in forests, on the glades or fenced nurseries, far away from local roads, villages, traffic, and other man-made disturbances. To be independent of electric power sup- 
ply we use solar panels with batteries, which permit long term field operation. "Good quality" recording places should guarantee high signal-to-noise ratio. The navy-blue dots in Fig. 3 show final locations of the stations (A0, B1-B6, C1-C6). Such a system of 13 stations apart of basic small triangles with side lengths of $30-40 \mathrm{~km}$ creates larger triangles with side lengths of $60-80$ and $90-110 \mathrm{~km}$.

Installation of a temporary broadband seismic station in northern Poland is shown in Fig. 4, and a scheme with elements of each station in the network is shown in Fig. 5.

The "13 BB star" network consists 13 stations, equipped with broadband seismometers: model Reftek 151-120 - "Observer". The "Observer" is a low noise seismometer, which contains three independent sensors (one vertical and two horizontal) with built-in electronic feedback circuit, control, and power conversion circuits, and large dynamic range. It is a force-balance feedback sensor with frequency bandwidth of $0.0083-50 \mathrm{~Hz}$ (which corresponds to periods 120-0.02 s), flat to velocity. It has built-in levelling and
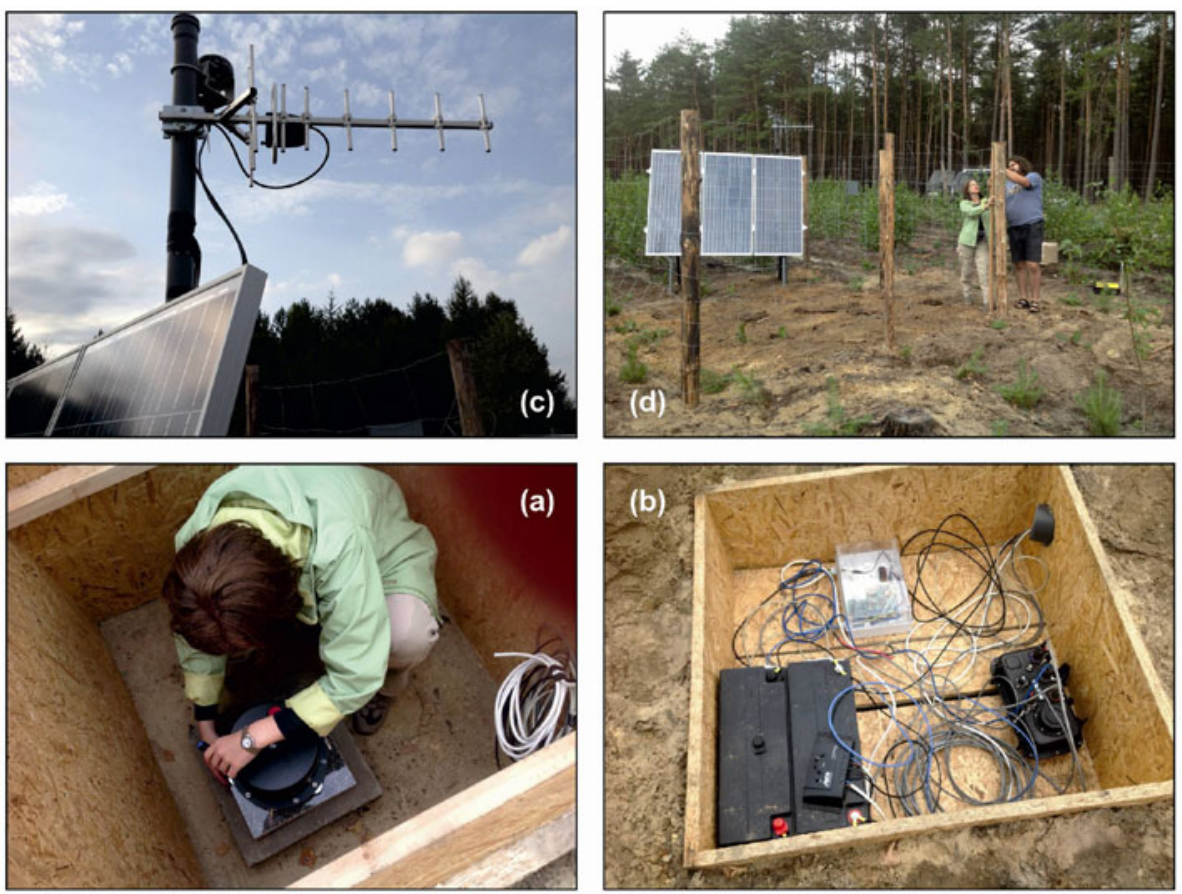

Fig. 4. Installation of the temporary broadband station in northern Poland: (a) Levelling broadband seismometer Reftek 151-120 on the granitic base in the $c a .1 \mathrm{~m}$ deep case; (b) Batteries, converter and recorder on the shelf, over the seismometer; (c) Solar panel, GPS and antenna for cell phone connection; (d) Closing the "garden" of seismic station in the forest area (photos taken by M. Grad, June 2013). 


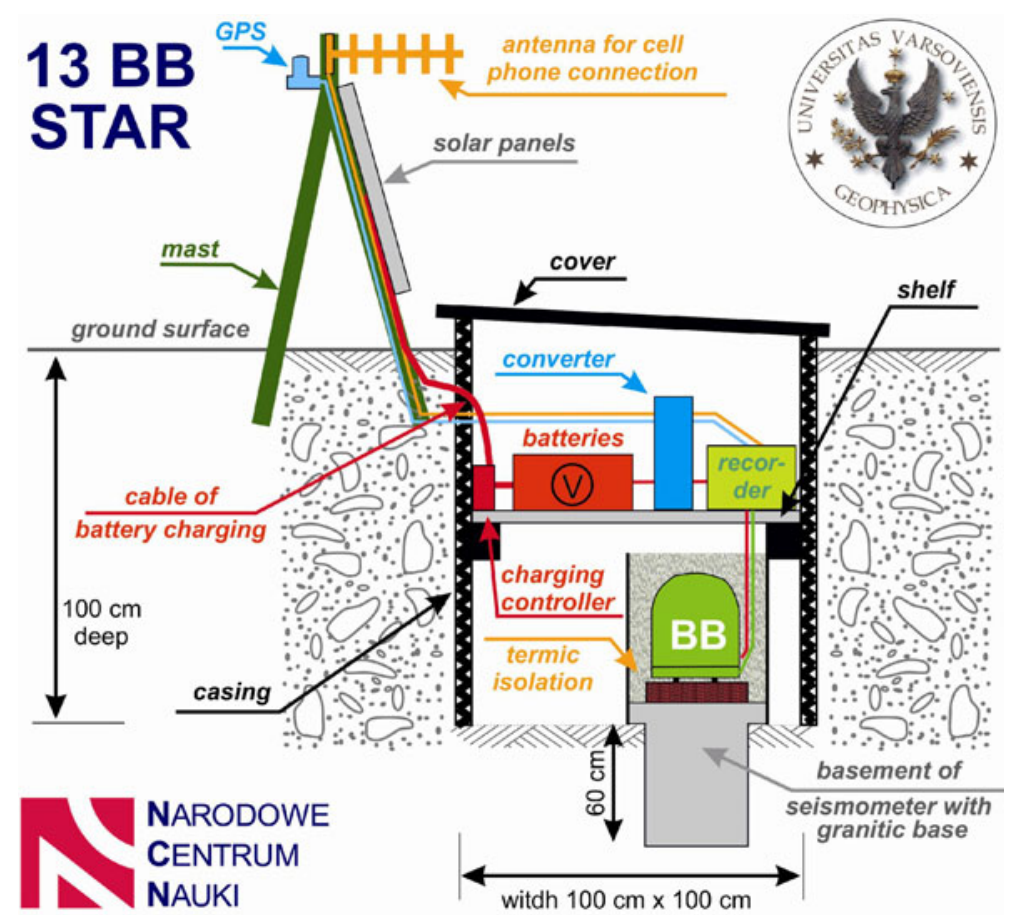

Fig. 5. Scheme of the station elements in temporary "13 BB star" network.

automatic mass zero-position adjusting mechanism. Monitoring and mass adjustment is performed via high resolution recorder Reftek 130B. All seismometers were placed on the $60 \mathrm{~cm}$ high reinforced concrete basement with granitic base in the ca. $1 \mathrm{~m}$ deep case with open bottom (Fig. 5). Above the seismometer, on the shelf, the recorder, own-design ARM Linux based data transmission set equipped with $3 \mathrm{G} / \mathrm{EDGE}$ wireless modem, and batteries were placed. The case was covered and masked with natural materials like sand, soil, and grass making the case invisible. Over the ground, solar panels, GPS and antenna for cell phone connection were installed. Finally, the "garden" of seismic station (size $4 \mathrm{~m} \times 4 \mathrm{~m}$ ) was fenced and closed.

In the "13 BB star" project a special attention will be paid to high-quality seismic network observations and modern interpretation methods. Solving of this problem has fundamental contribution for seismology, tectonics, and geodynamics, not only in the regional scale but also worldwide. The results of "13 BB star" project shall contribute to better basic knowledge on the structure of the Earth's interior, its physical properties, mantle dynamics, tectonic evolution, and present-day processes. The data acquired during the 3-years long recording campaign will be analysed using different modern seismic 
methods and integrated interpretations. They will yield images of detailed lithosphere-asthenosphere system hitherto unknown for the marginal zone of EEC in northern Poland. By applying surface waves, as well as the receiver function techniques, we expect to reveal variations of seismic velocities within the upper mantle. Regularity of network, its symmetry and size were chosen to enable gathering propagation properties of short, intermediate, and long period surface waves for all azimuths (Cotte et al. 2002, Bruneton et al. 2004). As shown, e.g., by Jiang et al. (2011) Rayleigh wave phase-velocity sensitivity depends on the period of wave. Short wave $(25 \mathrm{~s}$ period) has a peak sensitivity at about $25 \mathrm{~km}$ depth, and the longest wave (143 s period) has a peak sensitivity at about $200 \mathrm{~km}$ depth (see also Pasyanos 2010, Bartzsch et al. 2011). So, this is a depth we expect to reach using surface waves. Using receiver function technique " $410 "$ " "?520", and "660" km discontinuities beneath the marginal zone of EEC will be investigated. As part of the study in the marginal part of EEC, beneath our network, the anisotropy will be delineated. $S$-wave splitting, observations of $S K S$, and $S K K S$ phases will be collected from the network, and the polarization of the fastwaves will be determined. For strong events, in distance range of $30-40^{\circ}$, multiples of $S c S$ phase could be observed (mantle reverberations), and high frequency $P K P, S K S$, and other core phases (Kennett and van der Hilst 1996, Shearer et al. 2011).

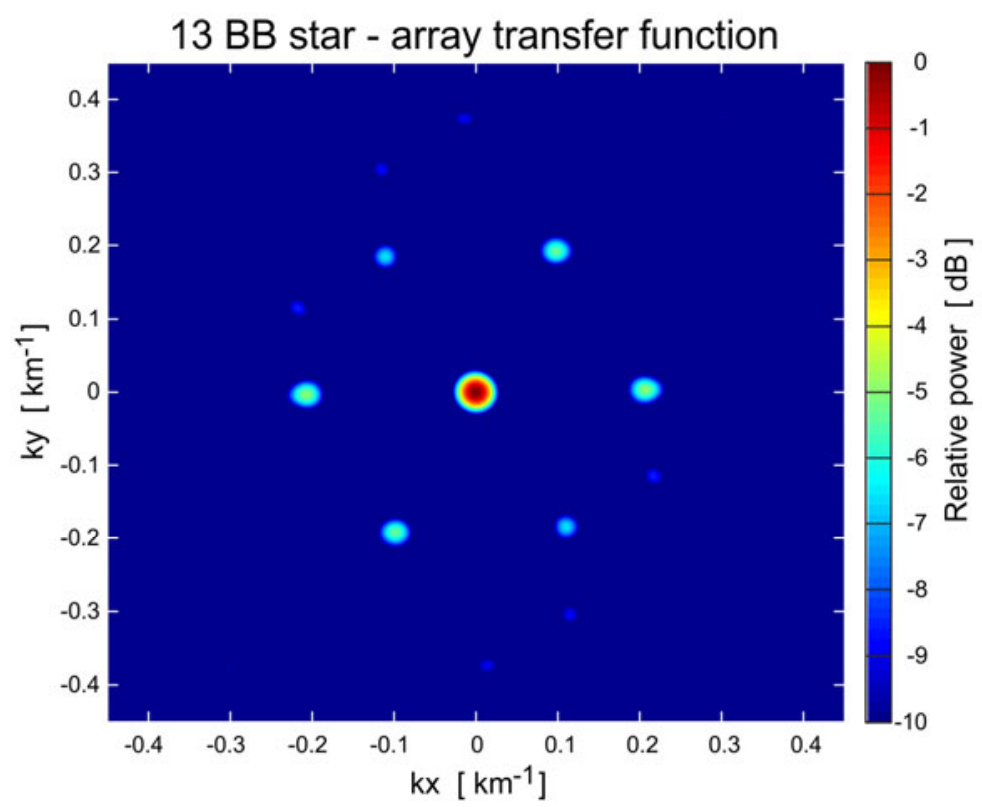

Fig. 6. Array transfer function of " 13 BB star" seismic network. Colours are related to power of the array response normalized with its maximum. 
The "13 BB star" network shape and station distribution may allow using some array analysis techniques. The evaluated array transfer function for "13 BB star" network is shown in Fig. 6. The wavenumber range of seismic signal, which can be investigated by "13 BB star" network using the array techniques, is $c a$. 0.05-0.2 1/ km (Schweitzer et al. 2012). So, the high resolution in measuring apparent velocities and backazimuth can be obtained only for teleseismic waves.

The "13 BB star" network could be also used to help in the detection of small natural seismic events (see, e.g., Wiszniowski et al. 2014). Poland is a region of very low natural seismicity. The largest earthquake with magnitude estimated at 5.6 occured on 3 December 1786, near Myślenice in southern Poland (see Fig. 2; Pagaczewski 1972). Over the last decade a few relatively strong earthquakes in Poland and surroundings have been widely felt in the area of Poland. The location of five events is shown in Fig. 2: two events close to Kaliningrad, near Jarocin, Bełchatów, and at Podhale. For more information see Domański (2007), Lizurek et al. (2013), Wiejacz and Rudziński (2010), and Wiejacz and Dębski (2009).

\section{FIRST RESULTS}

The "13 BB star" network started its operation on 19 July 2013. The recorded data are transmitted to central server dedicated for the project and available near on-line. All seismic data are sampled with $0.01 \mathrm{~s}$ (corresponding to $100 \mathrm{~Hz}$ ). Beside the seismic data, additional state of health information is constantly transmitted and includes temperature, voltage, and power measurements. Server is equipped with proprietary web interface for monitoring network status and allows preliminary seismic data analysis.

Station noise analysis is presented in Fig. 7. Probabilistic Power Spectral Densities (PPSD) allow comparison of noise level between stations and to permanent stations. For example, station C6 is closest to sea shore $(13.75 \mathrm{~km}$ in straight line), A0 is located close $(c a .100 \mathrm{~m})$ to local paved road with traffic of about 20-30 cars per day. Permanent station GKP is closest to "13 BB star" network, while KSP is located in southern Poland and has lowest noise along Polish Seismic Network. For all stations, PPSDs are calculated for the same period of 11 months (July 2013 - June 2014) for one-hour segments (PSDs) with 50\% overlap (Beyreuther et al. 2010, Megies et al. 2011). Only full one-hour segments are considered. All recorded data is considered for each station including seismic events (McNamara and Buland 2004). New high and low noise models (NHNM, NLNM) are shown for reference (Peterson 1993).

According to USGS/NEIC PDE Catalogue, in the period from 19 July 2013 to 24 June 2014, a total of 1543 earthquakes of magnitude $\geq 5.0$ and 440 earthquakes of magnitude $\geq 5.5$ occurred all over the word (Fig. 8). 

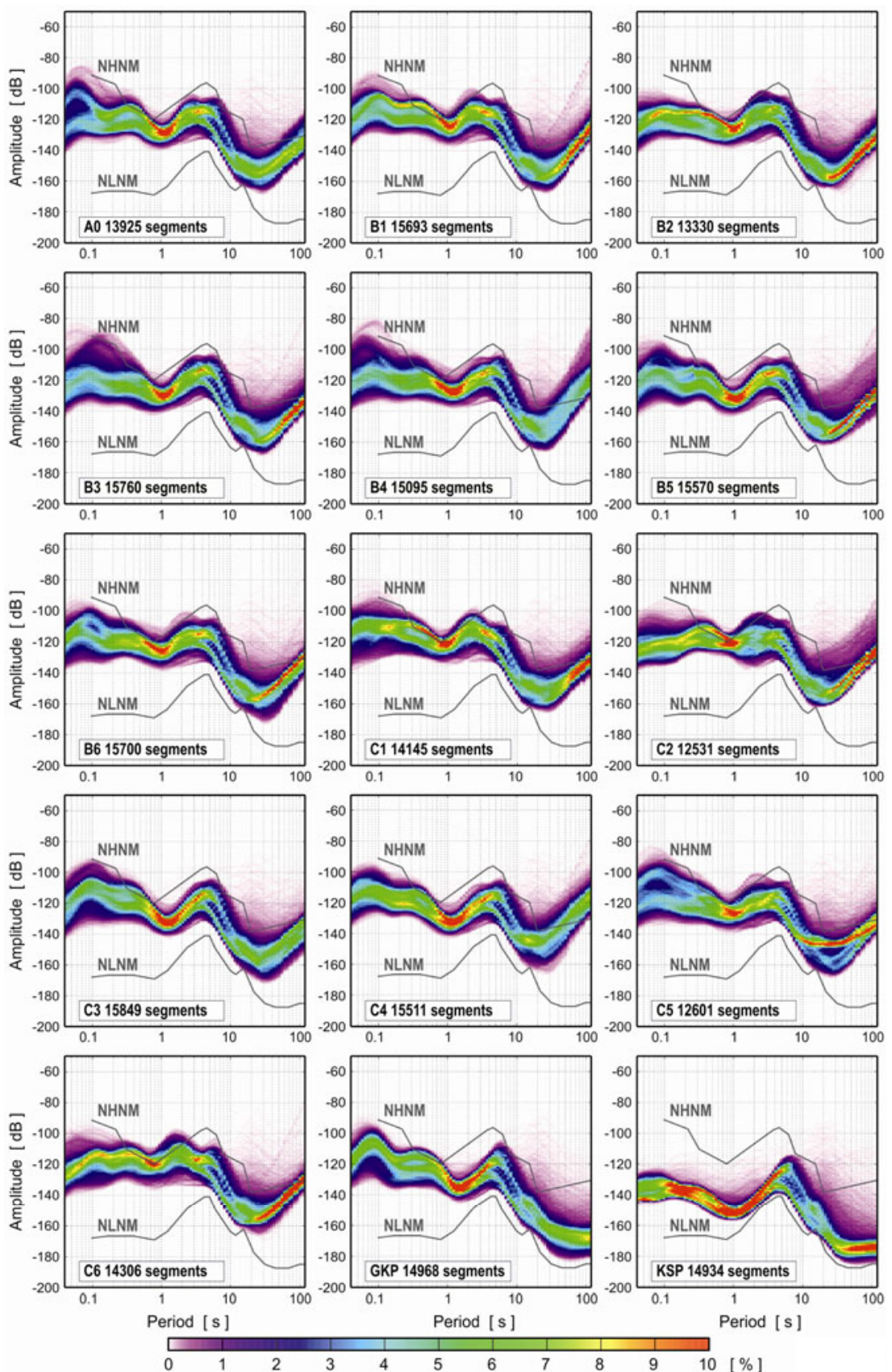

Fig. 7. Probabilistic Power Spectral Densities (PPSD) for all 13 stations and 2 permanent stations of Polish Seismic Network. New high and low noise models (NHNM, NLNM) are shown for reference (Peterson 1993). 

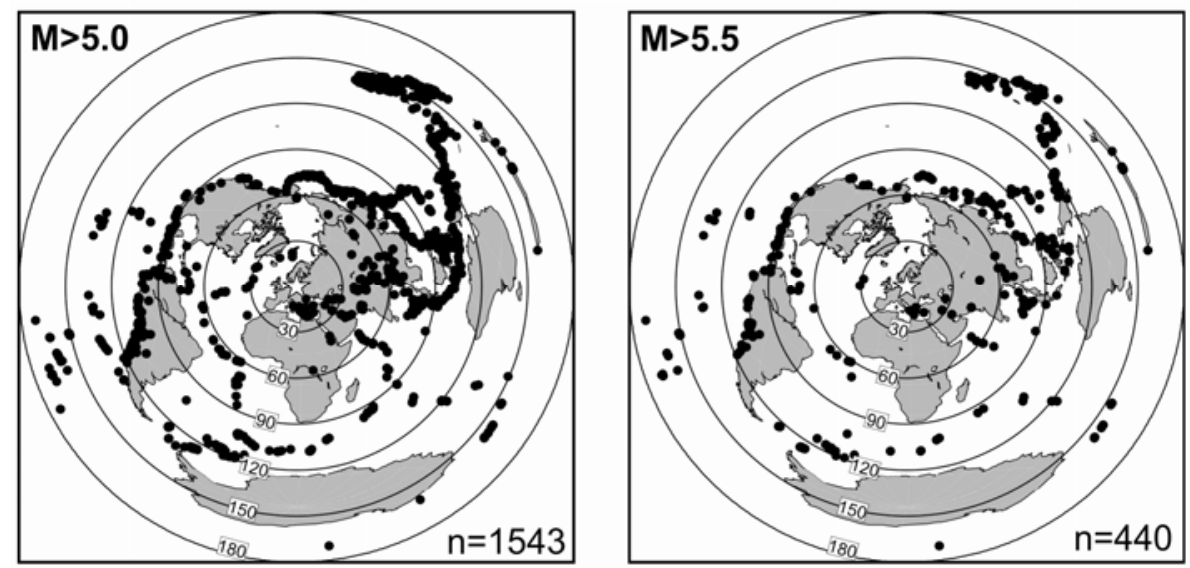

Fig. 8. Distribution of the earthquakes epicentres of magnitude $\geq 5.0$ (left plot, 1543 events) and of magnitude $\geq 5.5$ (right plot, 440 events) from 19 July 2013 to 24 June 2014 (according to USGS/NEIC PDE Catalogue). The azimuthal-equidistant projection shows the true distances and backazimuths of the epicentres with respect to the centre of " 13 BB star" network (marked by star). Circles show epicentral distances of $30^{\circ}, 60^{\circ}, 90^{\circ}, 120^{\circ}, 150^{\circ}$, and $180^{\circ}$.

Examples of records of " 13 BB star" network for five events are shown in Figs. 9-13 and their focal parameters are collected in Table 1. Figure 9 shows broadband seismograms of a teleseismic earthquake $\left(\Delta \approx 66^{\circ}\right)$ from the area of Okhotsk Sea. Figure 9a shows one hour records of $Z, N$, and $E$ components at station $\mathrm{C} 6$. The event has strong $P$ arrivals at $Z$ component, and strong $S$ arrivals at $N$ and $E$ components. The big depth of the earthquake $(h=570 \mathrm{~km})$ could explain a total lack of surface waves. Figure $9 \mathrm{~b}$ shows a zoom of $i P$ and $i S$ arrivals for all stations which confirms the uniform motion (indicated by arrows): "down" for $P$ waves at $Z$ component,

Table 1

Focal parameters of events recorded by " 13 BB star" network

\begin{tabular}{|c|r|r|r|r|l|c|c|c|}
\hline $\begin{array}{c}\text { Event } \\
\text { no. }\end{array}$ & Date & $\begin{array}{c}\text { Time UT } \\
\text { hh:mm:ss }\end{array}$ & $\begin{array}{c}\text { Lat. } \phi \\
{\left[{ }^{\circ} \mathrm{N}\right]}\end{array}$ & $\begin{array}{c}\text { Long. } \lambda \\
{\left[{ }^{\circ} \mathrm{E}\right]}\end{array}$ & Region & $\begin{array}{c}\text { Depth } \\
{[\mathrm{km}]}\end{array}$ & $M$ & $\begin{array}{c}\text { Distance } \\
\text { from A0 } \\
{[\mathrm{deg}]}\end{array}$ \\
\hline 1 & 1 Oct 2013 & $03: 38: 21$ & 53.17 & 152.88 & Okhotsk Sea & 570 & 6.7 & 66.52 \\
2 & 6 Oct 2013 & $01: 37: 21$ & 35.28 & 26.69 & Romania & 134 & 5.4 & 10.24 \\
3 & 24 Sep 2013 & $11: 29: 50$ & 27.06 & 65.56 & Pakistan & 30 & 7.4 & 44.05 \\
4 & 13 Aug 2013 & $15: 43: 14$ & 5.78 & -78.23 & South of Panama & 2 & 6.6 & 88.75 \\
5 & 15 Oct 2013 & $00: 12: 31$ & 9.93 & 124.16 & Philippines & 7 & 7.1 & 91.42 \\
\hline
\end{tabular}



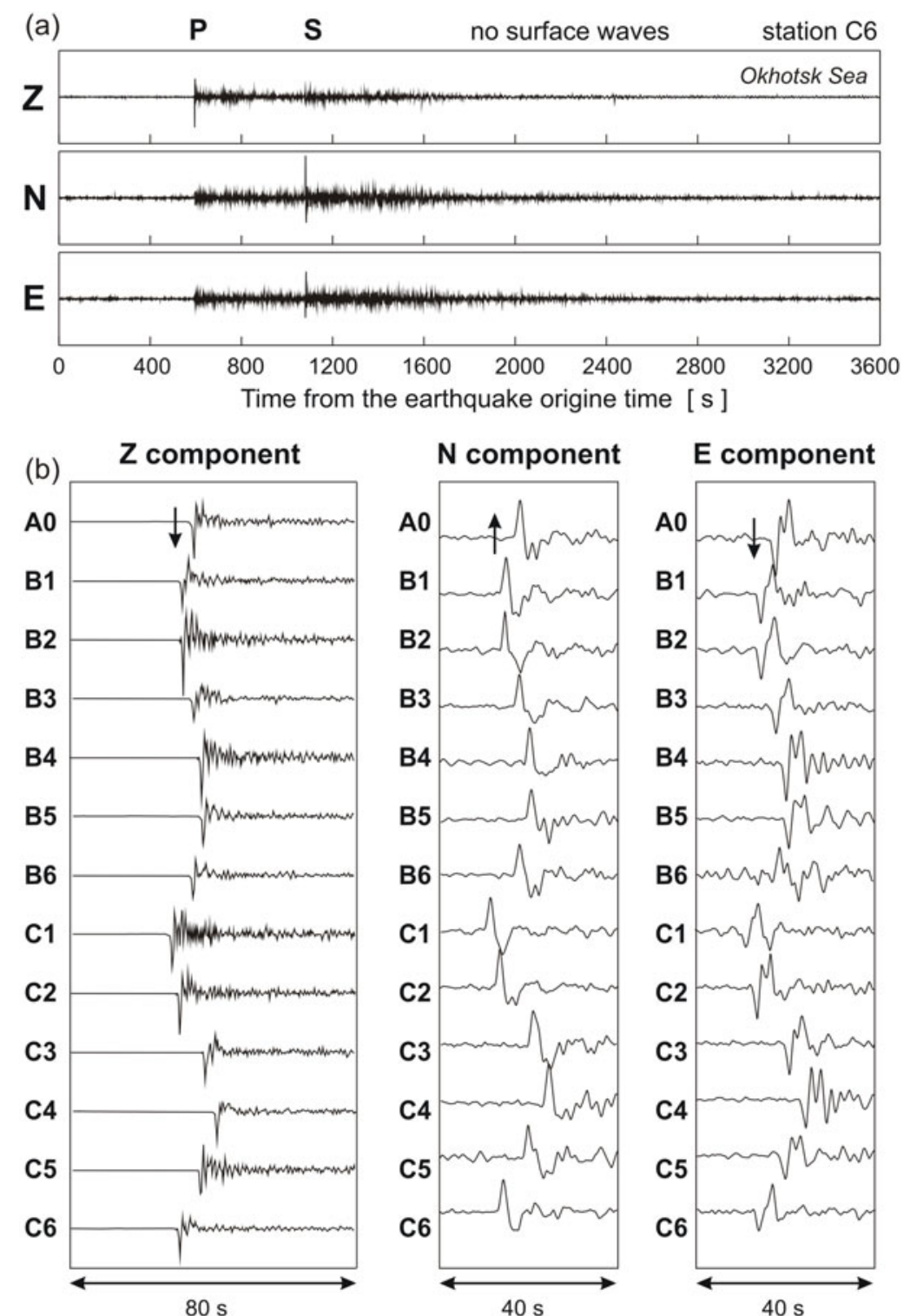

Fig. 9. Seismograms of a teleseismic earthquake from Okhotsk Sea region recorded by broadband network in northern Poland during passive experiment "13 BB star". Panel (a) shows one hour records of $Z, N$, and $E$ components at station C6. Note strong $P$ arrivals at $Z$ component, strong $S$ arrivals at $N$ and $E$ components, and no surface waves. Panel (b) with zoom of $i P$ and $i S$ arrivals shows for all stations uniform motion (indicated by arrows): "down" for $P$ waves at $Z$ component, "up" for $S$ waves at $N$ component, and "down" for $S$ waves at $E$ component. All traces are lowpass filtered $(<1 \mathrm{~Hz})$. 


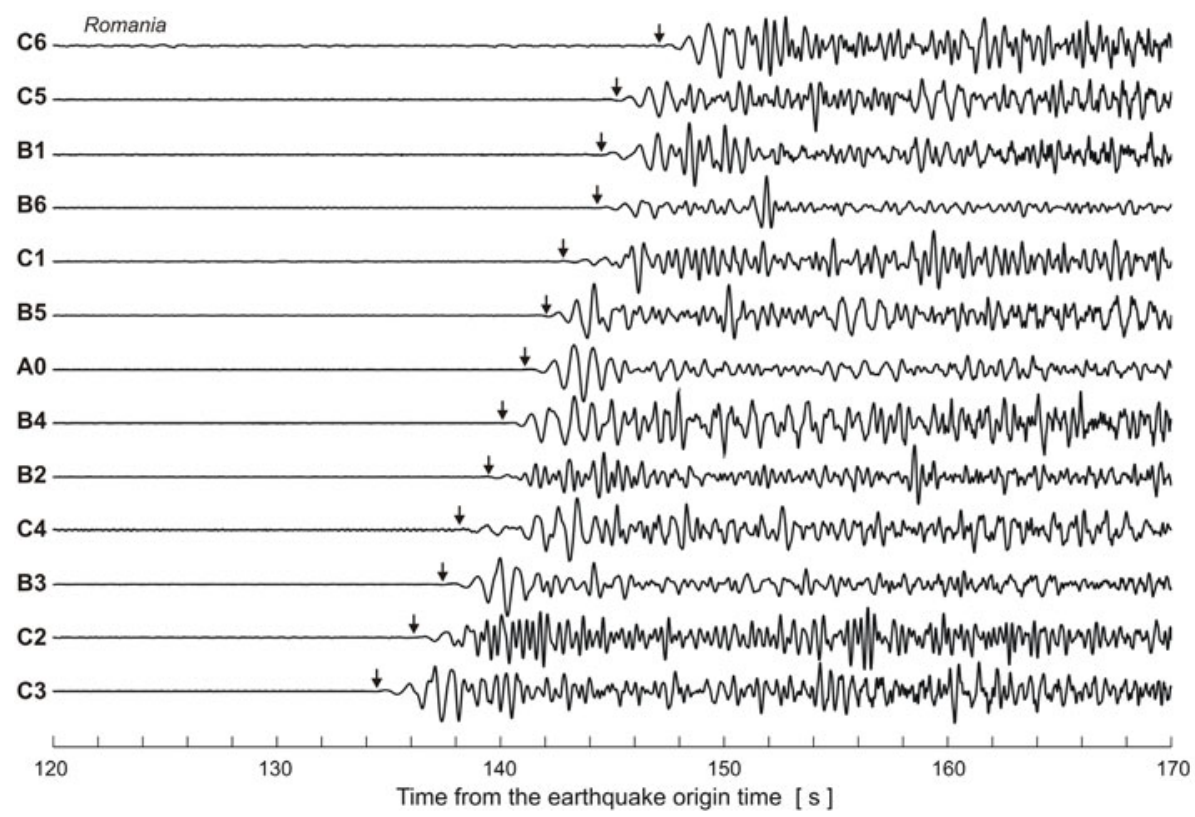

Fig. 10. Seismograms of a regional earthquake in Romania recorded by broadband network in northern Poland during passive experiment "13 BB star". Seismograms are sorted with distance from event. Note good signal-to-noise ratio and different shape of first $P$-wave arrivals (shown by arrows). All traces are highpass filtered $(>1 \mathrm{~Hz})$.

"up" for $S$ waves at $N$ component, and "down" for $S$ waves at $E$ component. Differentiation of arrival times is easily seen for this event: the arrival time difference across the network is ca. $6.3 \mathrm{~s}$ for $P$ waves and ca. $12.7 \mathrm{~s}$ for $S$ waves.

Seismograms of a regional earthquake from Romania $\left(\Delta \approx 10^{\circ}\right)$ recorded by broadband "13 BB star" network are shown in Fig. 10 with first $P$-wave arrivals marked by arrows. Note good signal-to-noise ratio and different shape of arrivals. Seismograms are sorted with distance from the event epicenter. For this event the time difference of $P$-wave arrivals across the network is $c a .12 \mathrm{~s}$. Seismograms of a teleseismic earthquake from Pakistan $\left(\Delta \approx 44^{\circ}\right)$ are shown in Fig. 11 . Note good signal-to-noise ratio, clear $P$ and $S$ arrivals, and dominant surface waves. All traces are lowpass filtered $(<1 \mathrm{~Hz})$. Figure 12 shows seismograms of a teleseismic earthquake from Panama $\left(\Delta \approx 88^{\circ}\right)$ recorded by " 13 BB star" network. Note strong $P, P P$, and surface waves with distinct dispersion. All traces are lowpass filtered $(<1 \mathrm{~Hz})$. Seismograms of the Philippines earthquake $\left(\Delta \approx 92^{\circ}\right)$ recorded by all stations are shown in Fig. 13. Note strong $P, P P, S$, and $S S$ arrivals, as 


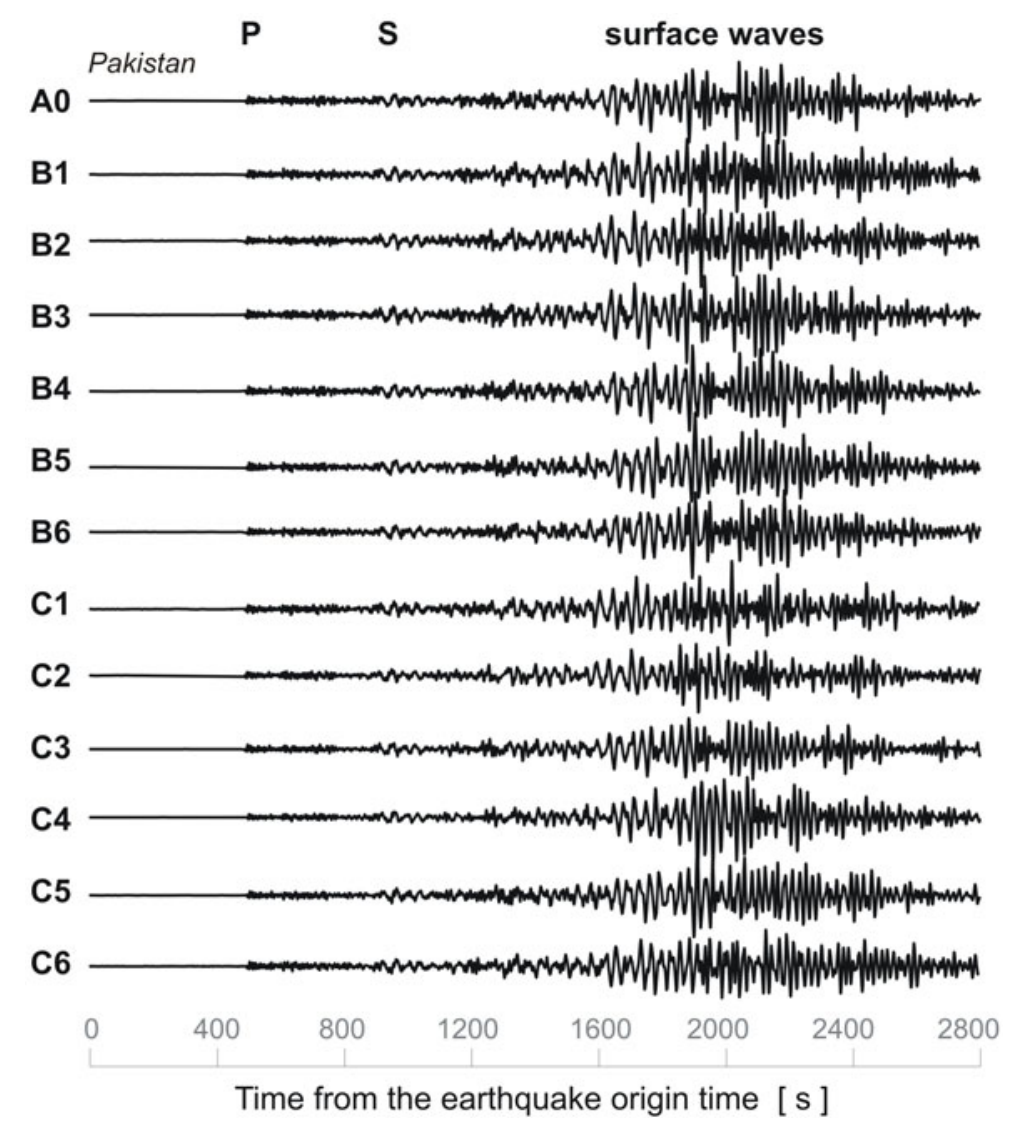

Fig. 11. Seismograms of a teleseismic earthquake in Pakistan recorded by broadband network in northern Poland during passive experiment "13 BB star". Note good signal-to-noise ratio and dominant surface waves. All traces are lowpass filtered $(<1 \mathrm{~Hz})$.

well as full wave field of surface waves with distinct dispersion and separation of $L Q$ and $L R$ waves. This earthquake was strong $(M=7.1)$ and relatively shallow $(h=7 \mathrm{~km})$; traces are not filtered.

The examples of seismograms presented in Figs. 9-13 show frequency differentiation for different seismic phases. More sophisticated representations of the records are displayed in Fig. 14 - spectral seismograms, which allow quantitative analyses of the frequency content of the recorded seismic phases. This technique was also employed for the determination of magnitude spectra, the source parameters, and discrimination between earthquakes and explosions (e.g., Duda et al. 1996, Domański 2007, Wilde-Piórko et al. 2011). Spectral seismograms obtained from the broadband seismograms of 


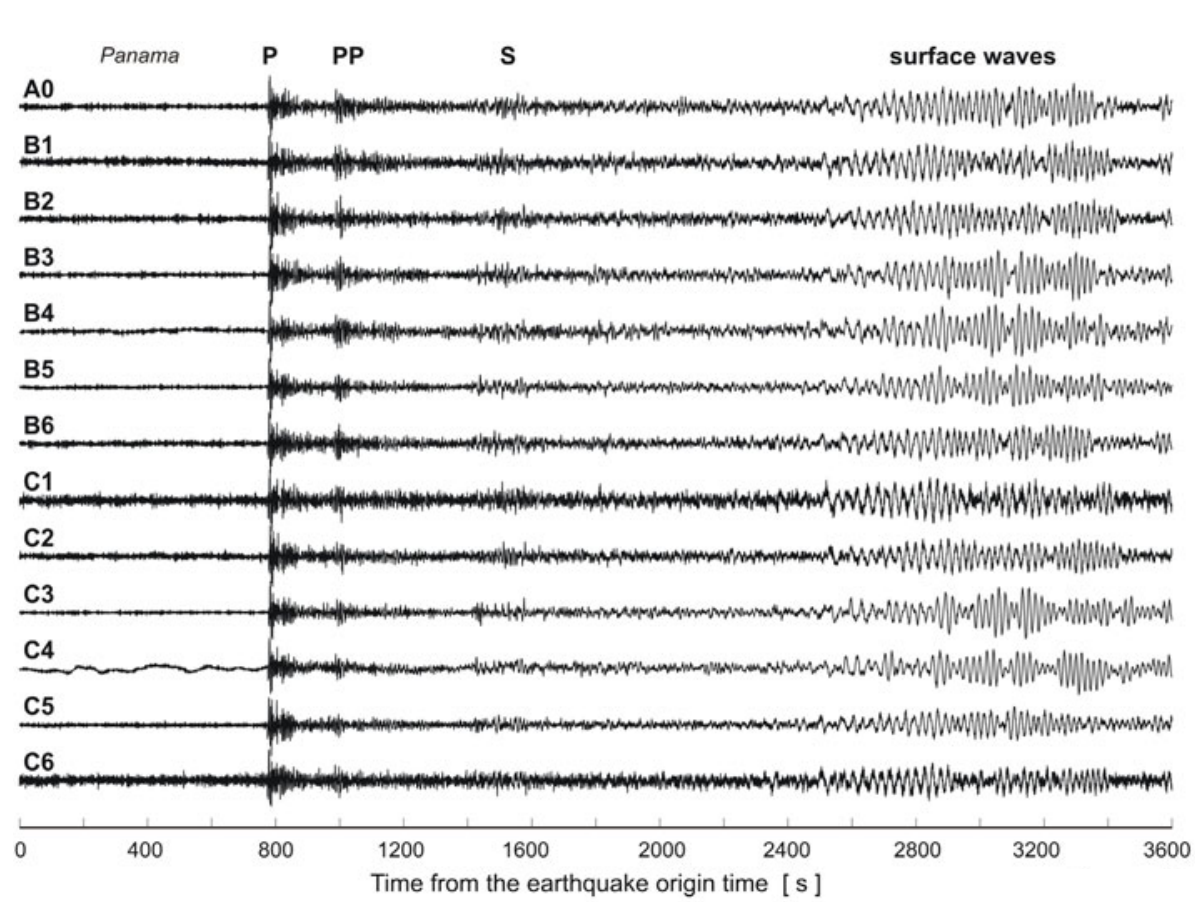

Fig. 12. Seismograms of a teleseismic earthquake in Panama recorded by broadband network in northern Poland during passive experiment " $13 \mathrm{BB}$ star". Note strong $P$, $P P$, and surface waves. All traces are lowpass filtered $(<1 \mathrm{~Hz})$.

four teleseismic events are shown in Fig. 14. They are obtained by applying Butterworth filters of order 2, with the widths of 0.5 octave (Fasthoff and Guo 2001).

An interesting case is the earthquake from Okhotsk Sea (Fig. 14a-c). The pulse of body waves is relatively short and strong. The maximum amplitude of $P$-wave radiation of this event is in the period range of $1-5 \mathrm{~s}$ (Fig. $14 \mathrm{a} ; Z$ component), while for stronger $S$-waves this period is $3-10 \mathrm{~s}$ (Fig. $14 \mathrm{~b}$ and c; $N$ and $E$ components, respectively). In the range of longer periods, a total lack of energy is observed, related with very deep source, which do not produce surface waves. In the spectral seismogram of the Pakistan earthquake (Fig. 14d; $Z$ component) dominant amplitudes are related to surface waves. Dispersion is easily seen: at time of $1400 \mathrm{~s}$ from the beginning of earthquake the maximum amplitude is observed for period $c a .90 \mathrm{~s}$, while for the time of $2500 \mathrm{~s}$ it is $20 \mathrm{~s}$ only. For the Panama earthquake (Fig. 14e; $Z$ component) a separation of surface waves is clear: the maximum amplitude of $L Q$-waves is observed for period ca. $90 \mathrm{~s}$ at time of $2600 \mathrm{~s}$, and for $L R$-waves this period is $20-10 \mathrm{~s}$ at time 2800-3400 s. For the Philippines earthquake (Fig. 14f; 


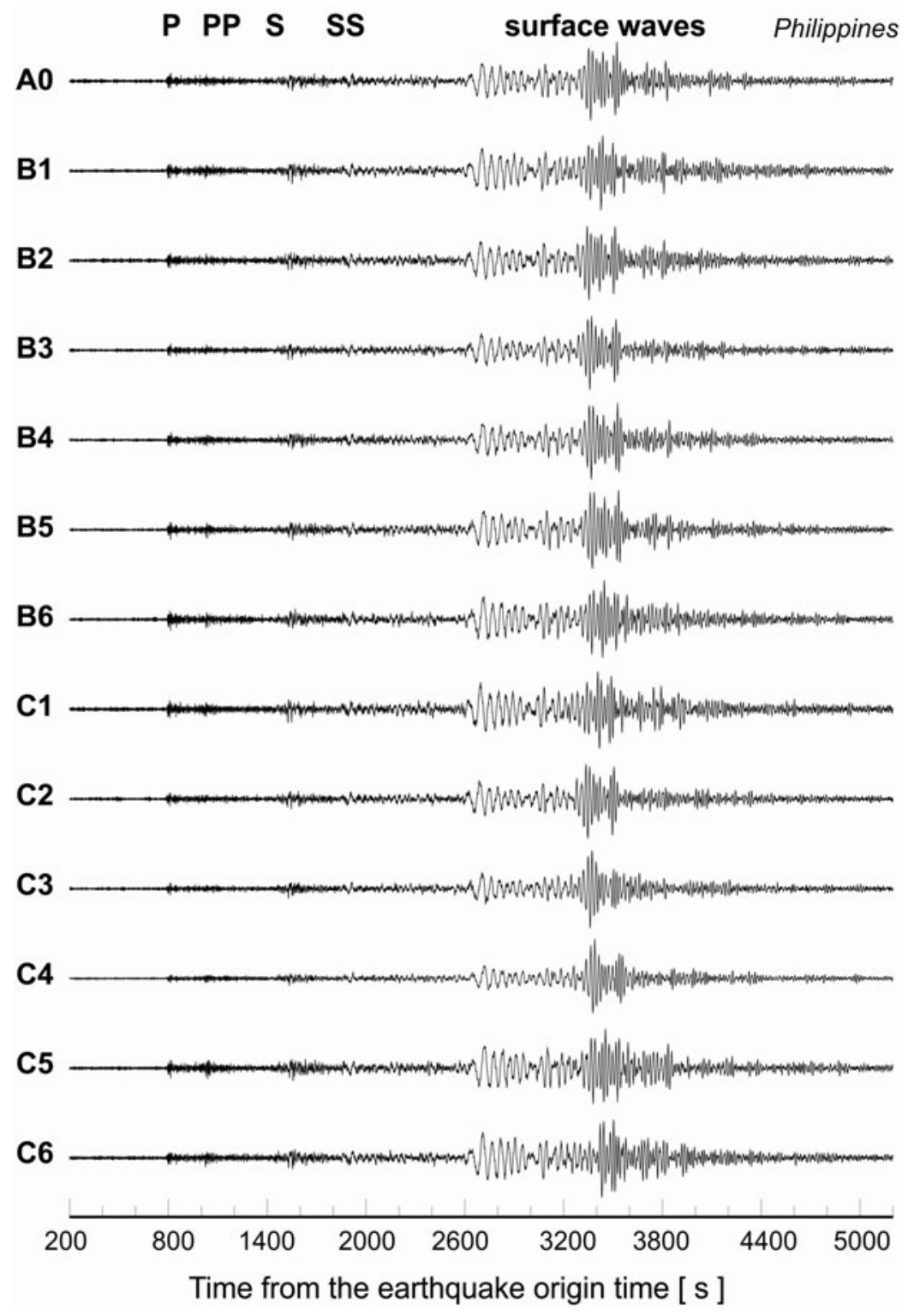

Fig. 13. Seismograms of a teleseismic earthquake from Philiphines recorded by broadband network in northern Poland during passive experiment "13 BB star". Note strong $P, P P, S$, and $S S$ arrivals, as well as full wave field of surface waves with distinct dispersion. Traces are not filtered.

$Z$ component) body waves are relatively weak, and dominant are $L Q$-waves with period $c a$. $70 \mathrm{~s}$ at time of $2800 \mathrm{~s}$. 

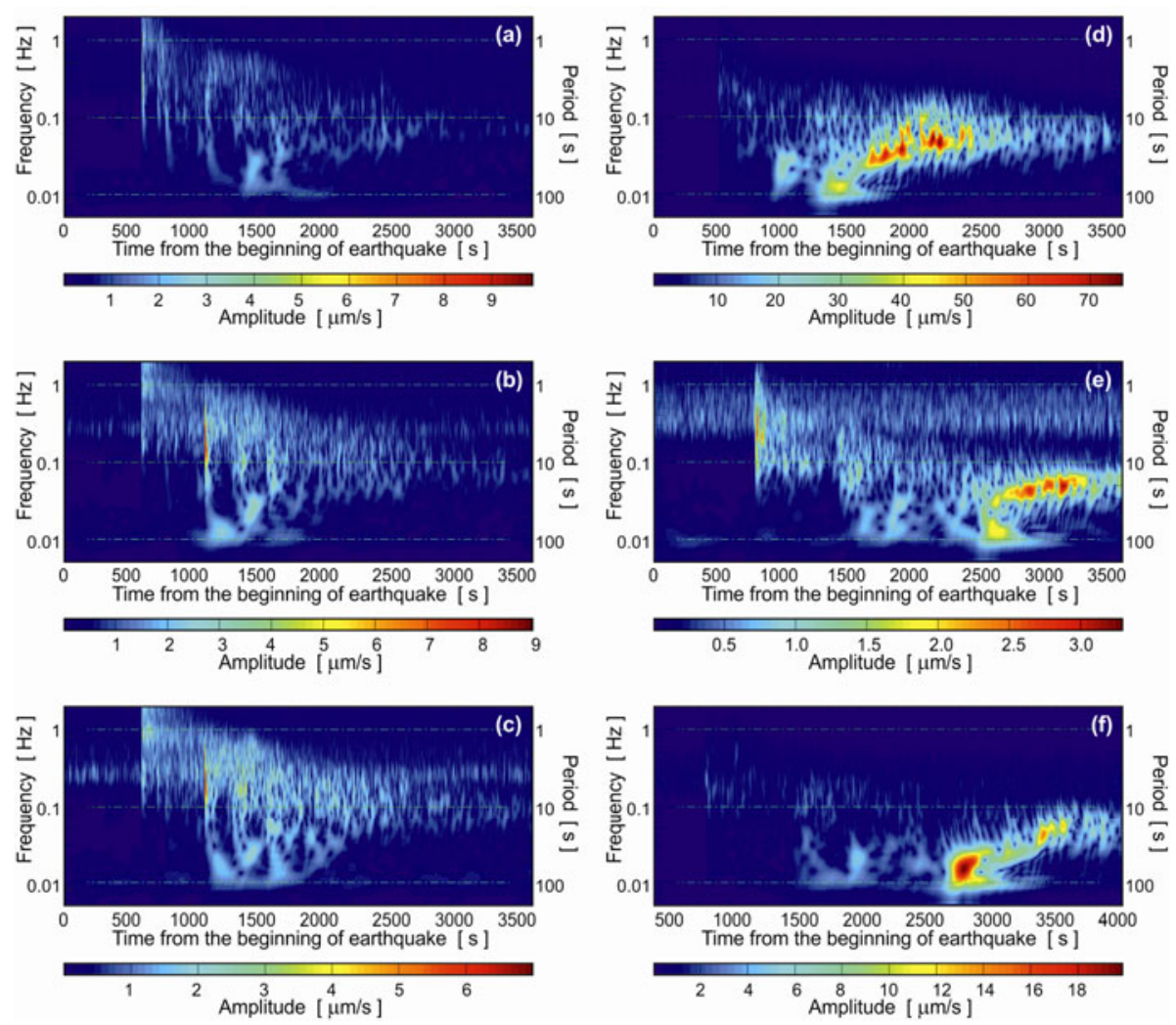

Fig. 14. Spectral seismograms obtained from records of the broadband network in northern Poland during passive experiment "13 BB star": (a), (b), and (c) spectral seismograms of the Okhotsk Sea earthquake recorded at station $\mathrm{C} 6$, for $Z, N$, and $E$ components, respectively; (d) spectral seismograms of the Pakistan earthquake recorded at station A0, $Z$ component; (e) spectral seismograms of the Panama earthquake recorded at station $\mathrm{C} 5, Z$ component; (f) spectral seismograms of the Philippines earthquake recorded at station A0, $Z$ component. All spectral seismograms were obtained by applying Butterworth filters of order 2, with the widths of 0.5 octaves. Note different amplitude scales.

\section{SUMMARY}

The knowledge of the Earth's lithosphere-asthenosphere system is far from complete. This is the main task of "13 BB star" experiment, and to solve this problem surface wave techniques and receiver function will be in use (see, e.g., Cotte et al. 2002, Bruneton et al. 2004, Wilde-Piórko et al. 2010, Trojanowski and Wilde-Piórko 2012). Using array techniques of broadband seismology, also deeper Earth's structure will be investigated: "410", "?520", and "670" km boundaries (Gossler and Kind 1996), and, if possible, 
also deep mantle and mantle-core boundary with $S$-wave splitting, $S c S, S K S$, and $S K K S$ phases (Kennett and van der Hilst 1996). The good knowledge of the crustal structure beneath the " 13 BB star" network is an advantage of its location. The knowledge of seismic wave velocity distribution in sedimentary cover is of great importance: for receiver function technique because of big sediments-basement velocity contrast (e.g., 2.5 to $6 \mathrm{~km} / \mathrm{s}$ ), and for seismic tomography, particularly in the cases of very deep basins, because of strongly differentiated velocities in thick strata. In the area of " 13 BB star" network, velocities in sediments are well known from vertical seismic profiling in deep boreholes and shallow refraction.

Finally, good records obtained till now, and expected during next 1-year long recording campaign, should yield images of detailed structure in the marginal zone of the EEC in northern Poland.

Acknowledgments. National Science Centre Poland provided financial support for this work by NCN grant DEC-2011/02/A/ST10/00284. The array transfer function calculation was done with support of NERA, EC Contract Number 0262330. The public domain GMT software (Wessel and Smith 1995) has been used to produce some of the figures. We thank very much reviewers for their valuable comments and remarks.

\section{References}

Bartzsch, S., S. Lebedev, and T. Meier (2011), Resolving the lithosphere-asthenosphere boundary with seismic Rayleigh waves, Geophys. J. Int. 186, 3, 1152-1164, DOI: 10.1111/j.1365-246X.2011.05096.x.

Berthelsen, A. (1998), The Tornquist Zone northwest of the Carpathians: An intraplate pseudosuture, GFF 120, 2, 223-230, DOI: 10.1080/ 11035899801202223.

Beyreuther, M., R. Barsch, L. Krischer, T. Megies, Y. Behr, and J. Wassermann (2010), ObsPy: A Python toolbox for seismology, Seismol. Res. Lett. 81, 3, 530-533, DOI: $10.1785 / \mathrm{gssrl} .81 .3 .530$.

Bogdanova, S., R. Gorbatschev, M. Grad, T. Janik, A. Guterch, E. Kozlovskaya, G. Motuza, G. Skridlaite, V. Starostenko, L. Taran, and EUROBRIDGE and POLONAISE Working Groups (2006), EUROBRIDGE: new insight into the geodynamic evolution of the East European Craton, Geol. Soc. London Mem. 32, 599-625, DOI: 10.1144/GSL.MEM.2006.032.01.36.

Bruneton, M., H.A. Pedersen, R. Farra, N.T. Arndt, P. Vacher, U. Achauer, A. Alinaghi, J. Ansorge, G. Bock, W. Friedrich, M. Grad, A. Guterch, P. Heikkinen, S.E. Hjelt, T.L. Hyvonen, J.P. Ikonen, E. Kissling, K. Komminaho, A. Korja, E. Kozlovskaya, M.V. Nevsky, H. Paulssen, N.I. 
Pavlenkova, J. Plomerova, T. Raita, O.Y. Riznichenko, R.G. Roberts, S. Sandoval, I.A. Sanina, N.V. Sharov, Z.H. Shomali, J. Tiikkainen, E. Wielandt, K. Wylegalla, J. Yliniemi, and Y.G. Yurov (2004), Complex lithospheric structure under the central Baltic Shield from surface wave tomography, J. Geophys. Res. 109, B10, B10303, DOI: 10.1029/2003JB 002947.

Cotte, N., H.A. Pedersen, and TOR Working Group (2002), Sharp contrast in lithospheric structure across the Sorgenfrei-Tornquist Zone as inferred by Rayleigh wave analysis of TOR1 project data, Tectonophysics 360, 1-4, 75-88, DOI: 10.1016/S0040-1951(02)00348-7.

Domański, B.M. (2007), Source parameters of the 2004 Kaliningrad earthquakes, Acta Geophys. 55, 3, 267-287, DOI: 10.2478/s11600-007-0021-7.

Duda, S.J., J. Saul, and M. Grad (1996), The influence of near-source and nearreceiver structure on the spectrum of $P$ waves from nuclear explosions, Acta Geophys. Pol. 44, 1, 1-18.

Eaton, D.W., F. Darbyshire, R.L. Evans, H. Grütter, A.G. Jones, and X. Yuan (2009), The elusive lithosphere-asthenosphere boundary (LAB) beneath cratons, Lithos 109, 1-2, 1-22, DOI: 10.1016/j.lithos.2008.05.009.

Fasthoff, S., and L. Guo (2001), On spectral seismograms - 3D display of seismogram, CT Theor. Appl. 10, 3, 47-51.

Gossler, J., and R. Kind (1996), Seismic evidence for very deep roots of continents, Earth Planet. Sci. Lett. 138, 1-4, 1-13, DOI: 10.1016/0012-821X(95)00215$\mathrm{X}$.

Grabowska, T., G. Bojdys, M. Bielik, and K. Csicsay (2011), Density and magnetic models of the lithosphere along CELEBRATION 2000 profile CEL01, Acta Geophys. 59, 3, 526-560, DOI: 10.2478/s11600-011-0007-3.

Grad, M. (1986), Seismic P-wave velocities of the East European Platform in Poland, Acta Geophys. Pol. 34, 1, 21-29.

Grad, M., and M. Polkowski (2012), Seismic wave velocities in the sedimentary cover of Poland: Borehole data compilation, Acta Geophys. 60, 4, 9851006, DOI: 10.2478/s11600-012-0022-z.

Grad, M., G.R. Keller, H. Thybo, A. Guterch, and POLONAISE Working Group (2002), Lower lithospheric structure beneath the Trans-European Suture Zone from POLONAISE'97 seismic profiles, Tectonophysics 360, 1-4, 153-168, DOI: 10.1016/S0040-1951(02)00350-5.

Grad, M., S.L. Jensen, G.R. Keller, A. Guterch, H. Thybo, T. Janik, T. Tiira, J. Yliniemi, U. Luosto, G. Motuza, V. Nasedkin, W. Czuba, E. Gaczyński, P. Środa, K.C. Miller, M. Wilde-Piórko, K. Komminaho, J. Jacyna, and L. Korabliova (2003), Crustal structure of the Trans-European suture zone region along POLONAISE'97 seismic profile P4, J. Geophys. Res. 108, B11, 2541, DOI: 10.1029/2003JB002426. 
Grad, M., T. Tiira, and ESC Working Group (2009), The Moho depth map of the European Plate, Geophys. J. Int. 176, 1, 279-292, DOI: 10.1111/j.1365246X.2008.03919.x.

Guterch, A., and M. Grad (2006), Lithospheric structure of the TESZ in Poland based on modern seismic experiments, Geol. Quart. 50, 1, 23-32.

Jiang, M., S. Zhou, E. Sandvol, X. Chen, X. Liang, Y.J. Chen, and W. Fan (2011), 3-D lithospheric structure beneath southern Tibet from Rayleigh-wave tomography with a 2-D seismic array, Geophys. J. Int. 185, 2, 593-608, DOI: 10.1111/j.1365-246X.2011.04979.x.

Jóźwiak, W. (2013), Electromagnetic study of lithospheric structure in the marginal zone of East European Craton in NW Poland, Acta Geophys. 61, 5, 11011129, DOI: 10.2478/s11600-013-0127-z.

Kennett, B.L.N., and E.R. Engdahl (1991), Traveltimes for global earthquake location and phase identification, Geophys. J. Int. 105, 2, 429-465, DOI: 10.1111/j.1365-246X.1991.tb06724.x.

Kennett, B.L.N, and R.D. van der Hilst (1996), Using a synthetic continental array to study the Earth's interior, J. Phys. Earth 44, 6, 669-674, DOI: 10.4294/ jpe1952.44.669.

Kozlovskaya, E., G. Kosarev, I. Aleshin, O. Riznichenko, and I. Sanina (2008), Structure and composition of the crust and upper mantle of the ArcheanProterozoic boundary in the Fennoscandian shield obtained by joint inversion of receiver function and surface wave phase velocity of recording of the SVEKALAPKO array, Geophys. J. Int. 175, 1, 135-152, DOI: 10.1111/ j.1365-246X.2008.03876.x.

Królikowski, C., and Z. Petecki (1997), Crustal structure at the Trans-European Suture Zone in northwest Poland based on the gravity data, Geol. Mag. 134, 5, 661-667, DOI: 10.1017/S0016756897007395.

Krysiński, L., M. Grad, and POLONAISE Working Group (2000), POLONAISE'97 - Seismic and gravimetric modelling of the crustal structure in the Polish basin, Phys. Chem. Earth A 25, 4, 355-363, DOI: 10.1016/S1464-1895(00) 00057-0.

Lizurek, G., B. Plesiewicz, P. Wiejacz, J. Wiszniowski, and J. Trojanowski (2013), Seismic event near Jarocin (Poland), Acta Geophys. 61, 1, 26-36, DOI: 10.2478/s11600-012-0052-6.

Majdański, M. (2012), The structure of the crust in TESZ area by kriging interpolation, Acta Geophys. 60, 1, 59-75, DOI: 10.2478/s11600-011-0058-5.

Majorowicz, J.A., V. Čermak, J. Šafanda, P. Krzywiec, M. Wróblewska, A. Guterch, and M. Grad (2003), Heat flow models across the Trans-European Suture Zone in the area of the POLONAISE'97 seismic experiment, Phys. Chem. Earth 28, 9-11, 375-391, DOI: 10.1016/S1474-7065(03)00059-7.

Malinowski, M. (2013), Models of the Earth's crust from controlled-source seismology - Where we stand and where we go? Acta Geophys. 61, 6, 1437-1456, DOI: $10.2478 / \mathrm{s} 11600-013-0156-7$. 
McNamara, D.E., and R.P. Buland (2004), Ambient noise levels in the continental United States, Bull. Seismol. Soc. Am. 94, 4, 1517-1527, DOI: 10.1785/ 012003001.

Megies, T., M. Beyreuther, R. Barsch, L. Krischer, and J. Wassermann (2011), ObsPy - What can it do for data centers and observatories? Ann. Geophys. 54, 1, 47-58, DOI: 10.4401/ag-4838.

Meissner, R. (1986), The Continental Crust - A Geophysical Approach, International Geophysics Series, Vol. 34, Academic Press Inc., Orlando, 426 pp.

Młynarski, S. (1984), The structure of deep bedrock in Poland on the basis of refraction results, Publs. Inst. Geophys. Pol. Acad. Sci. A-13, 160, 87-100.

Pagaczewski, J. (1972), Catalogue of earthquakes in Poland in 1000-1970 years, Publs. Inst. Geophys. Pol. Acad. Sci. 51, 3-36.

Pasyanos, M.E. (2010), Lithospheric thickness modeled from long-period surface wave dispersion, Tectonophysics 481, 1-4, 38-50, DOI: 10.1016/j.tecto. 2009.02.023.

Peterson, J. (1993), Observation and modeling of seismic background noise, U.S. Dept. of Interior, Geological Survey, Open-file Rep. 93-322, 95 pp.

Pharaoh, T.C., R.W. England, J. Verniers, and A. Żelaźniewicz (1997), Introduction: geological and geophysical studies in the Trans-European Suture Zone, Geol. Mag. 134, 5, 585-590, DOI: 10.1017/S0016756897007619.

Pożaryski, W., W. Brochwicz-Lewiński, and H. Tomczyk (1982), Sur la caractére hétérochronique de la Ligne Teisseyre-Tornquist, entre Europe centrale et orientale, C.R. Acad. Sci. Paris II Tect. 295, 691-696 (in French).

Romanowicz, B. (2009), The thickness of tectonic plates, Science 324, 5926, 474476, DOI: $10.1126 /$ science.1172879.

Sandoval, S., E. Kissling, J. Ansorge, and the SVEKALAPKO Seismic Tomography Working Group (2004), High-resolution body wave tomography beneath the SVEKALAPKO array - II. Anomalous upper mantle structure beneath the central Baltic Shield, Geophys. J. Int. 157, 1, 200-214, DOI: 10.1111/ j.1365-246X.2004.02131.x.

Schweitzer, J., J. Fyen, S. Mykkeltveit, S.J. Gibbons, M. Pirlii, D. Kühn, and T. Kværna (2012), Seismic arrays. In: P. Bormann (ed.), New Manual of Seismological Observatory Practice 2 (NMSOP-2), Deutsches GeoForschungsZentrum, Potsdam, 1-80, DOI: 10.2312/GFZ.NMSOP2 ch9.

Shearer, P.M., C.A. Rychert, and Q. Liu (2011), On the visibility of the inner-core shear wave phase PKJKP at long periods, Geophys. J. Int. 185, 3, 13791383, DOI: 10.1111/j.1365-246X.2011.05011.x.

Skorupa, J. (1974), Seismic velocity map of Poland 1:500 000, Wyd. Geol., Warszawa. 
Trojanowski, J., and M. Wilde-Piórko (2012), S-velocity structure beneath the Bohemian Massif from Monte Carlo inversion of seismic receiver function, Acta Geophys. 60, 1, 76-91, DOI: 10.2478/s11600-011-0047-8.

Wessel, P., and W.H.F. Smith (1995), The Generic Mapping Tools GMT Version 3, Technical reference and cookbook, School of Ocean and Earth Science and Technology, University of Hawaii, Manoa, NOAA.

Wiejacz, P., and W. Dębski (2009), Podhale, Poland, earthquake of November 30, 2004, Acta Geophys. 57, 2, 346-366, DOI: 10.2478/s11600-009-0007-8.

Wiejacz, P., and Ł. Rudziński (2010), Seismic event of January 22, 2010 near Bełchatów, Poland, Acta Geophys. 58, 6, 988-994, DOI: 10.2478/s11600010-0030-9.

Wilde-Piórko, M., M. Świeczak, M. Grad, and M. Majdański (2010), Integrated seismic model of the crust and upper mantle of the Trans-European Suture zone between the Precambrian craton and Phanerozoic terranes in Central Europe, Tectonophysics 481, 1-4, 108-115, DOI: 10.1016/j.tecto.2009.05. 002.

Wilde-Piórko, M., S.J. Duda, and M. Grad (2011), Frequency analysis of the 2004 Sumatra-Andaman earthquake using spectral seismograms, Acta Geophys. 59, 3, 483-501, DOI: 10.2478/s11600-011-0010-8.

Wiszniowski, J., B.M. Plesiewicz, and J. Trojanowski (2014), Application of real time recurrent neural network for detection of small natural earthquakes in Poland, Acta Geophys. 62, 3, 469-485, DOI: 10.2478/s11600-013-0140-2.

Ziegler, P.A. (1990), Geological Atlas of Western and Central Europe, 2nd ed., Shell Int. Petrol. Maatschappij, Hague, Geological Society Publ. House, London.

Znosko, J. (1975), Tectonic units of Poland against the background of the tectonics of Europe, Geol. Inst. Anniversary Bull. 252, 61-75.

Znosko, J. (1979), Teisseyre-Tornquist tectonic zone: some interpretative implications of recent geological and geophysical investigations, Acta Geol. Pol. 29, 4, 365-382.

Received 17 March 2014

Received in revised form 7 June 2014 Accepted 10 December 2014 